\title{
Customer satisfaction as a mediation between micro banking image, customer relationship and
} customer loyalty

\author{
Sri Hayatia, Agus Suroso ${ }^{a}$, Suliyanto ${ }^{a}$ and M. Elfan Kaukab ${ }^{b^{*}}$
}

${ }^{a}$ Economics and Business Faculty, Universitas Jenderal Soedirman, Purwokerto, Indonesia

${ }^{b}$ Economics and Business Faculty, Universitas Sains Al-Qur'an Jawa Tengah, Indonesia

\section{CH R O N I C L E}

Article history:

Received: February 19, 2020

Received in revised format:

March 272020

Accepted: March 29, 2020

Available online:

March 30, 2020

Keywords:

Micro banking image

Loyalty

Satisfaction

Consumer relations

\section{Introduction}

The government pays attention on micro financing, considering it important since micro financing is deemed able to solve poverty and economic inequality. Micro financing needs more attention since many people do not have access to cheap and easy financing from financial institution, particularly bank. The other reasons are that the people's business credit (KUR) program transmitted by the government has not reached micro businesses and that financing programs recently made by banks do not have an integrated information system. This causes everyone or every business has access to more than one financing program, which will result in more burdens to customers. Many non-bank financing institutions perform operation in segments which are not penetrated by banks. However, this has not been empowered to expand the financing capacity in micro segment (Anonymous, 2018). The competition of micro financing service in Central Java is fairly strict, since there are nineteen micro financing providers in Central Java until 2016 (Anonymous, 2016). Therefore, each company needs to apply appropriate marketing strategy to acquire customers and make them loyal to it. Loyal customers will make repeated purchase. Customers' decision to make repeated purchase is determined by several factors, one of which is company image (Giovanis, Zondiros, \& Tomaras, 2014; Hart \& Rosenberger III, 2004; Kandampully \& Suhartanto, 2000). Assael (1984) explains image as overall perception of a product or a company developed based on acquired and processed information. Rein, Kotler, and Haider

* Corresponding author. Tel.: +62 8156685076

E-mail address: elvankaukab@yahoo.com (M. Elfan Kaukab)

(C) 2020 by the authors; licensee Growing Science, Canada doi: $10.5267 /$ j.msl.2020.3.039 
(1993) state that overall image refers to customers' trust in, impression and ideas of a company, brand, product, service or goal. Company image adopted from shop image is explained that image is formed in buyer's mind (Martineau, 1958). Image is reflected in its functional quality and partly by aura of psychological attributes. Image constitutes customers' overall perception (Doyle \& Fenwick, 1974; Keaveney \& Hunt, 1992; Ngobo \& Jean, 2012). Image is formed by customers from the results of overall evaluation of a company and its offerings, or even from image assessment based on certain product category (LeBlanc \& Nguyen, 1996). Image also becomes part of decision making (Brunner, Stöcklin, \& Opwis, 2008).

Company manages to have good image with expectation that customers will become loyal. Loyal customers may lead to company's future profitability. Loyalty is commitment felt by customers to the people of company, products, and services. Griffin (1995) defines loyal customer as a customer who makes regular purchase, makes purchase in all product and service lines, becomes reference of others and shows immunity from competitor's attractiveness. Customer loyalty is also defined as word of mouth recommendation and possible brand improvement, and repeated purchase of goods or services offered by a company (Lee, Lee, \& Feick, 2001). Pearson (1996) also defines customer loyalty as customer's mindset in maintaining good attitude toward a company, commitment to repurchasing a company's products or services, and recommending service or product to others. Regular purchase will lead to future profit. Therefore, efforts are needed to maintain customer loyalty, and any variables influencing customer loyalty need to be identified. Customer loyalty may be enhanced by making customer satisfied, since loyalty is the result of customer satisfaction (Oliver, 1997). According to Liang, Choi, and Joppe (2018), a transaction which takes place based on customer satisfaction will reduce customer's intention to shift to other brand. Satisfaction may also enhance customer's repurchase intention. This shows that making customer satisfied will lead to customer loyalty to company. Castaldo, Grosso, Mallarini, and Rindone (2016) present a research result that the more satisfied a customer of a product or service, his/her trust and loyalty will be enhanced. Customer satisfaction is a person's level of feeling upon comparing a performance or result with what is expected (Kotler \& Amstrong, 2004). Dissatisfaction arises when a result gained does not fulfill customer's expectation. Customer satisfaction will influence his/her repurchase behavior of a service from the same service provider (Liang et al., 2018; Woodside, Frey, \& Daly, 1989). An effort to establish customer satisfaction is to establish company image. This company image power needs to be maintained and enhanced to acquire customers and make them satisfied. This shows that company image is important to enhance customer satisfaction, pursuant to the research results (Lahap, Ramli, Said, Radzi, \& Zain, 2016). In addition to image, customer satisfaction is established by establishing good relationship with customers. This good relationship with customers is part of relationship marketing, in which relationship marketing is stated as company's method to develop mutual and valuable long-term relationship with customers (Ravald \& Grönroos, 1996). Establishing customer relationship needs customer relationship management, which is a series of systematic activities managed as an effort to obtain better understanding, attract attention, and maintain profitable customer loyalty in achieving company's healthy growth. Customer relationship is a series of customer oriented activities supported by organization's strategy and technology and designed to increase customer interactions in establishing customer loyalty and increasing profit over time (Padmavathy, Balaji, \& Sivakumar, 2012). Nyadzayo and Khajehzadeh (2016) propose that customer relationship management influences customer loyalty, appropriately to the research conducted by Zhang, Li, Wang, and Wang (2016). The research shows that customer relationship management may establish positive company image in customer's mind. Company's strategy to establish customer relationship will be able to establish the customer loyalty level of those who are satisfied with company's performance. Marketing performed by establishing relationship with customers also influences customer satisfaction (Mithas, Krishnan, \& Fornell, 2005).

\section{Literature Review and Hypotheses}

\subsection{Loyalty}

Customer loyalty is part of expected behaviors related to a company's products or services. Loyalty may be observed from two elements of customer loyalty, which are loyalty to make repurchase and giving recommendation to other customer. These two elements are similar to the measurement used in the previous researches (Cronin Jr, Brady, \& Hult, 2000; Cronin Jr \& Taylor, 1992). Based on the description, customer loyalty may be measured with loyalty to make purchase and also giving others information of interesting transactional experience as well as giving others recommendation to make the same transaction. Loyalty is defined as word of mouth recommendation and possible enhancement of brand power, as well as repurchase of goods or services offered by a company (Lee et al., 2001). Pearson (1996) defines customer loyalty as customer's mindset to maintain positive behavior to a company, commitment to repurchase company's products or services, and recommendation of product and service improvement to others. In e-commerce context, customer loyalty is defined as customer's good behavior toward e-commerce which results in repeated purchase behavior (Anderson \& Srinivasan, 2003; S.-C. Chen, 2012)

\subsection{Image}

Lee et al. (2010) state that behavior may be predicted by image. One of the variables in such behavior is repurchase intention and recommending others (Brunner et al., 2008). Repurchase intention and recommending others are part of loyalty (Cronin Jr \& Taylor, 1992). Besides customer satisfaction, image is an important variable to influence intention and is often deemed having the strongest relationship with intention (Brunner et al., 2008). Any effort to strengthen product or service image will strengthen customer's intention to be loyal (Ostrowski, O'Brien, \& Gordon, 1993) either directly (Bloemer \& De Ruyter, 
1998; Wallin Andreassen \& Lindestad, 1998) or indirectly (Bloemer and Ruyter, 1998). Previous researches suggest to include image together with other variables into customer's determinants of decision making (Brunner et al., 2008; J.-S. Lee et al., 2010). Another definition of image is (customer's) perception of a company as reflected in the relationship between customer and company recorded in customer's memory (Keller, 1993). Image is also defined as overall perception of a product or a company developed based on acquired and processed information (Assael, 1984). Image as overall image refers to customer's trust, impression and ideas of a company, brand, product, service, or goal (Rein et al., 1993). Company image is related to different elements of retailer marketing mixture, in which there are eight elements: placement, merchandise, shop atmosphere, customer service, price, advertisement, salesmanship and sale incentive program. Each retailer shop has image, and such image is differently perceived in customer's mind. Retailer must convincingly offer its products to their expected customers. However, the other non-functional elements must be in line with customer's expectation in sequence (Bloemer \& De Ruyter, 1998). It is believed that company image has the same characteristic, to influence purchase decision. Good company image stimulates purchase from a company by simplifying decision making principle. In company image, this context becomes an issue of trust and behavior of recognition and awareness, customer behavior and customer satisfaction. Company image may be a sign of information caused by external condition of both potential purchase and whether something may influence customer loyalty. As consequence, company image is assumed to have an impact on the choice of a company's customers when evaluation of service attribute is difficult. Company image is formed and developed in managing customers through communication and experience. Company image is believed to create a halo effect with regard to customer satisfaction. When customers are satisfied with a given service, their behavior toward company is improved. This attitude will then influence customer satisfaction of that company (Bloemer \& De Ruyter, 1998). Bolton and Drew (1991) propose that company image positively influences customer satisfaction. Likewise, (Chang \& Fong, 2010; Lai, Griffin, \& Babin, 2009; Wallin Andreassen $\&$ Lindestad, 1998)propose that Company image positively influence customer satisfaction. Besides its influence on customer satisfaction, company image also influences customer loyalty (Giovanis et al., 2014; Hart \& Rosenberger III, 2004; Kandampully \& Suhartanto, 2000). Therefore, the following hypotheses are formulated in this research:

$\mathrm{H}_{1}$ : Company image positively influences customer satisfaction.

$\mathrm{H}_{2}$ : Company image positively influences customer loyalty.

\subsection{Satisfaction}

Customer satisfaction has been repeatedly defined from various sources. Satisfaction is defined as overall evaluation of fulfillment of needs, from dissatisfying to satisfying. Satisfaction is the result of difference between what is expected and what is experienced (Albaity \& Melhem, 2017; Chen \& Chen, 2010; Truong \& Foster, 2006). Satisfaction in journey is defined as the difference between expectation before journey and experience after journey (Albaity \& Melhem, 2017; Pizam, Neumann, \& Reichel, 1978). Customer satisfaction is customer's response to evaluation of perceived appropriateness between expected and actual performance of a product perceived after it has been used (Tjiptono, 2004). Customer satisfaction is customer's evaluation after purchase in which the chosen alternative at least provides the same outcome or exceeds customer's expectation, while dissatisfaction arises when the outcome obtained does not meet customer's expectation or, in other words, customer satisfaction is a person's feeling after comparing the performance (or outcome) he/she perceives and his/her expectation (Tjiptono, 2004). During and after consuming and using a product or service, customer develops satisfaction or dissatisfaction. Customer satisfaction is defined as any behavior with regard to good or service after it has been received and used (Mowen \& Minor, 2002). In other words, satisfaction is choice after evaluation of assessment of a specific transaction (Cronin Jr \& Taylor, 1992). (Fornell, 1992) proposes that satisfaction may be directly expected as overall feeling, and customer has idea of how a product or service is compared with an "ideal" norm. In general, when a product, service fails (its performance is below expectation), customer will attempt to determine the reason of such failure. If its reason is any attribute of the product or service, dissatisfaction tends to take place. Conversely, when its reason is coincidence factor or his/her own behavior, dissatisfaction is less likely to take place (Mowen \& Minor, 2002). Researches which agree to the existence of influence of customer satisfaction on customer loyalty are those conducted by Yang and Peterson (2004), El-Adly and Eid (2016) and Han and Hyun (2018). Based on the research results, the following hypothesis is formulated:

\section{$\mathrm{H}_{3}$ : Customer satisfaction positively influences customer loyalty.}

\subsection{Customer relationship}

Relationship marketing is a process employed to draw, maintain, and strengthen customer relationship (Grönroos, 2007). Customer retention will be enhanced with relationship marketing established on a long-term basis (Wang \& Head, 2005). Company will benefit from strong relationship between customer and company, in which the company will acquire very valuable information of how to best serve customers and to prevent customers from shifting to competitor (Nyadzayo \& Khajehzadeh, 2016; Olavarría-Jaraba, Cambra-Fierro, Centeno, \& Vázquez-Carrasco, 2018). Company and customer will mutually benefit from good relationship (Dewani, Sinha, \& Mathur, 2016; Olavarría-Jaraba et al., 2018). The relationship marketing concept is useful in developing new definition of concept such as relationship quality, which is the appropriateness level of relationship to fulfill the needs of customers who are related to the relationship (Hennig-Thurau \& Klee, 1997). 
Relationship marketing may be employed as a strategy designed to grow long-term customer loyalty, interaction, and involvement (Nakhleh, 2012). In this sense, long-term and short-term customer relationships allow company to gather useful information from customers and, with adequate management, provide superior value as source of competitive superiority (Ndubisi, 2004). Therefore, enhancing relationship quality will lead to customers' higher desire to maintain relationship (Al-Alak, 2014). With regard to customer relationship, company administers customer relationship management/CRM. CRM focuses on making, managing and expanding relationship between company and its customers (Bolton, 2016; Hyun \& Perdue, 2017). CRM is part of marketing management in a company. In marketing act, a company expects contribution to the enhancement of customer's behavior and preference which, in turn, influences the depth and strength of relationship between company and its customers, which then enhances customers' lifetime monetary value which, in aggregate, contributes to customer equity and profit of marketing investment (Hyun \& Perdue, 2017; Rust, Lemon, \& Zeithaml, 2004). The relationship between relationship marketing and customer satisfaction and loyalty has been previously studied. Based on the research conducted by Nyadzayo and Khajehzadeh (2016) and the research conducted by Zhang et al. (2016), the influence of customer relationship management on customer loyalty may be examined. The results of research conducted by Zhang et al. (2016) also shows the influence of relationship marketing on company image. Relationship marketing also influences customer satisfaction, appropriately to the results of research conducted by (Hassan, Nawaz, Lashari, \& Zafar, 2015). Based on previous research results, the following hypotheses are formulated:

$\mathrm{H}_{4}$ : Customer relationship positively influences company image.

$\mathrm{H}_{5}$ : Customer relationship positively influences customer satisfaction.

$\mathrm{H}_{6}$ : Customer relationship positively influences customer loyalty

That company image influences customer satisfaction (Wallin Andreassen \& Lindestad, 1998) and customer satisfaction influences customer loyalty (Yang and Peterson (2004), El-Adly and Eid (2016) as well as research conducted by Han and Hyun (2018)) shows the role of customer satisfaction as a variable which connects company image and customer loyalty. Similarly, that customer relationship influences customer satisfaction (Hassan et al., 2015) and customer satisfaction influences (loyalty Nyadzayo and Khajehzadeh (2016) as well as research conducted by Zhang et al. (2016)), the following hypotheses are formulated:

$\mathrm{H}_{7}$ : Customer satisfaction may become mediation variable between company image and customer loyalty.

$\mathrm{H}_{8}$ : Customer satisfaction may become mediation variable between customer relationship and customer loyalty.

\section{Methods}

\subsection{Data collection}

The research is conducted by surveying the customers of micro banking BPR BKK in Banjarnegara Regency, Central Java Province. This research employs closed questionnaire as its instrument with alternative answer with bipolar adjective with 1 to 10 scaled answer. This scale is an improvement of semantic scale with an expectation to generate response in the form of interval scaled data. Every respondent is asked for agreement or disagreement to each question given with interval scale using Bipolar Adjective 10 points technique. This is only to give two extreme categories (Ferdinand, 2002). Hypothesis test procedure is conducted using path analysis with software structural equation modeling. The first hypothesis to sixth hypotheses are tested in view of Critical Ratio value. Mediation is tested to test the seventh and eighth hypotheses using the procedure developed by Sobel (Ghozali, 2006) known as Sobel test.

\subsection{Measures}

This research studies the relationship of image, customer relationship, customer satisfaction and customer loyalty variables. Image is measured using six indicators of company image according to (Bloemer \& De Ruyter, 1998), which are location, merchandise, customer service, price, advertising, and personal selling. Customer satisfaction is measured using indicators (Dimitriades, 2006) of overall satisfaction of company, company's constant fulfillment of customer's expectation, interesting experience and not overlooking company. Customer relationship is tested with Customer relationship management dimension consisting of competence, communication, conflict handling, trust, and relationship quality.(Padmavathy et al., 2012). Loyalty may be measured with word of mouth, repurchase, identification (Ratanavaraha, Jomnonkwao, Khampirat, Watthanaklang, \& Iamtrakul, 2016), and recommendation to other customers (Cronin Jr et al., 2000; Cronin Jr \& Taylor, 1992).

\subsection{Analysis}

Data analysis techniques were carried out by analyzing structural equation modeling to examine the effect of exogenous variables on endogenous variables. Data is obtained from micro banking customers who are at least one year old customers to be able to better assess micro banking. The selected micro banking is an intensive banking system that builds relationships with customers. 


\section{Results and Discussion}

\subsection{Validity and reliability of measures}

This research employs survey, thus it needs dimensionality, reliability and convergent validity tests. The results of test of dimensionality, reliability and convergent validity may be viewed in Table 1 . Based on Table 1 , we may examine that the loading factor value of micro banking image variable ranges from 0.793 to 0.849 . The result of Cronbach's alpha reliability test of micro banking image variable is 0.920 , with composite reliability of 0.923 and AVE value of 0.667 . The loading factor value of customer relationship variable ranges from 0.723 to 0.811 . The result of Cronbach's alpha reliability test of customer relationship variable is 0.887 , with composite reliability of 0.888 and AVE value of 0.614 . The loading factor value of customer satisfaction variable ranges from 0.772 to 0.813 .

Table 1

Dimensionality, reliability and convergent validity statistics

\begin{tabular}{|c|c|c|c|c|c|c|}
\hline Variable & Indicator & Loading factor & Cronbach & $\mathbf{C R}$ & Composite reliability & AVE \\
\hline Micro banking & I1 & 0.793 & 0.920 & & 0.923 & 0.667 \\
\hline \multirow[t]{5}{*}{ Image } & $\mathrm{I} 2$ & 0.828 & & 9.555 & & \\
\hline & $\mathrm{I} 3$ & 0.817 & & 9.078 & & \\
\hline & I4 & 0.813 & & 9.222 & & \\
\hline & I5 & 0.849 & & 9.174 & & \\
\hline & I6 & 0.798 & & 8.698 & & \\
\hline Customer & $\mathrm{R} 1$ & 0.723 & 0.887 & & 0.888 & 0.614 \\
\hline \multirow[t]{4}{*}{ Relationship } & $\mathrm{R} 2$ & 0.801 & & 8.406 & & \\
\hline & $\mathrm{R} 3$ & 0.783 & & 8.205 & & \\
\hline & R4 & 0.796 & & 8.764 & & \\
\hline & R5 & 0.811 & & 7.744 & & \\
\hline \multirow{4}{*}{$\begin{array}{c}\text { Customer } \\
\text { Satisfaction }\end{array}$} & $\mathrm{S} 1$ & 0.787 & 0.867 & & 0.868 & 0.622 \\
\hline & $\mathrm{S} 2$ & 0.772 & & 8.278 & & \\
\hline & $\mathrm{S} 3$ & 0.813 & & 7.664 & & \\
\hline & $\mathrm{S} 4$ & 0.783 & & 7.874 & & \\
\hline \multirow{4}{*}{$\begin{array}{l}\text { Customer } \\
\text { Loyalty }\end{array}$} & L1 & 0.748 & 0.882 & & 0.889 & 0.667 \\
\hline & L2 & 0.882 & & 8.384 & & \\
\hline & L3 & 0.799 & & 8.025 & & \\
\hline & L4 & 0.833 & & 8.189 & & \\
\hline
\end{tabular}

The result of Cronbach's alpha reliability test of customer satisfaction variable is 0.867 , with composite reliability of 0.868 and AVE value of 0.622 . The loading factor of customer loyalty variable ranges from 0.748 to 0.882 . The result of Cronbach's alpha reliability test of customer loyalty variable is 0.882 , with composite reliability of 0.889 and AVE value of 0.667 . Based on the results of dimensionality test, the micro banking image, customer relationship, customer satisfaction and customer loyalty variables are unidimensional since their loading factor values are more than 0,7 . The results of construct reliability test show Cronbach's alpha value higher than 0.6 and composite reliability higher than 0.7 , which mean that the micro banking image, customer relationship, customer satisfaction and customer loyalty variables qualify for reliability. Their AVE values are higher than 0.5 , which shows that more diversities may be caught by the construct compared to diversities generated by measurement error. Based on Table 2, we may examine that the correlation square value is lower than the AVE value, which shows that the studied variables qualify discriminant validity.

Table 2

Discriminant validity: AVEs versus cross-construct squared correlations

\begin{tabular}{cccccc}
\hline & Mean & Stdev & I & CR & CS \\
\hline Micro Banking Image & 8.177 & 0.922 & $\mathbf{0 . 6 6 6 7}$ & & \\
Customer relationship & 8.136 & 0.769 & 0.0949 & $\mathbf{0 . 6 1 3 8}$ & \\
Customer satisfaction & 7.993 & 0.793 & 0.1310 & 0.1391 & $\mathbf{0 . 6 2 2 4}$ \\
Customer loyalty & 8.158 & 1.013 & 0.1954 & 0.2181 & 0.2153 \\
\hline
\end{tabular}

Explanation: Diagonal shows AVE value

\subsection{Finding}

The hypotheses in this research are tested using path analysis in assistance of SEM AMOS software. The results of path analysis in path diagram drawn using SEM AMOS may be viewed in Fig. 1. Based on Fig. 1, we may examine the results of path analysis and Goodness of fit index value. The Goodness of index values consist of chi square $=174.744$, probability $=$ $0.052, \mathrm{Cmin} / \mathrm{df}=1.197, \mathrm{RMSEA}=0.045, \mathrm{GFI}=0.856, \mathrm{AGFI}=0.813, \mathrm{CFI}=0.975$ and $\mathrm{TLI}=0.970$. The goodness of fit index values provides information that there is Goodness of fit index indicator which has not shown that the model is fit, in which the GFI and AGFI values are less than 0.9. There is goodness of fit index value which provides information of Goodness of fit index indicator which shows that the model is fit, which is probability of which value is higher than 0.05 , Cmin/df less than 2, RMSEA less than 0.08, CFI and TLI values less than 0.95. The Goodness of fit index values show that the models used in this research are not strong ones, since there is marginal goodness of fit index based on the GFI and AGFI values. 


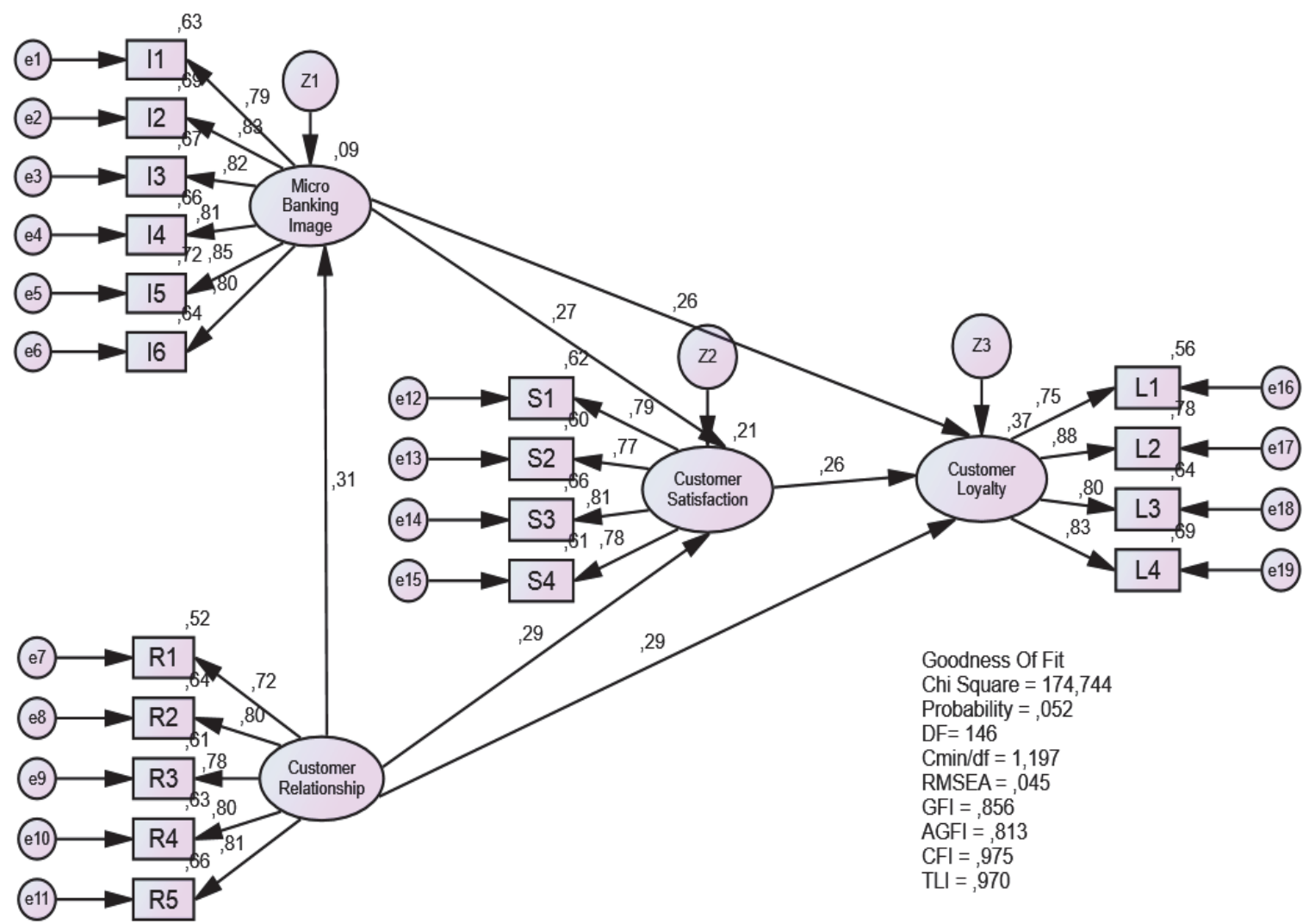

Table 3

Fig. 1. Result of Path Analysis

Hypotheses test results

\begin{tabular}{|c|c|c|c|c|c|c|c|}
\hline Hypothesis & Independent Variable & Dependent Variable & Standardized estimated & S.E & T value & P value & Result \\
\hline H1 & Micro banking image & Customer satisfaction & 0.273 & 0.0870 & 2.4010 & 0.0160 & Support \\
\hline $\mathrm{H} 2$ & Micro banking image & Customer loyalty & 0.257 & 0.1100 & 2.4120 & 0.0160 & Support \\
\hline $\mathrm{H} 3$ & Customer satisfaction & Customer loyalty & 0.263 & 0.1530 & 2.2990 & 0.0210 & Support \\
\hline $\mathrm{H} 4$ & Customer relationship & Micro banking image & 0.308 & 0.1430 & 2.7660 & 0.0060 & Support \\
\hline H5 & Customer relationship & Customer satisfaction & 0.289 & 0.1530 & 2.2990 & 0.0210 & Support \\
\hline H6 & Customer relationship & Customer loyalty & 0.29 & 0.1460 & 2.6250 & 0.0090 & Support \\
\hline
\end{tabular}

Based on Table 3, we may examine that micro banking image has positive path coefficient against customer satisfaction, which is 0.273 with $T$ value of 2.4010 and $P$ value $=0.0160$. This shows that the $t$ count value of path coefficient of micro banking image variable against customer satisfaction is within H0's area of rejection, which means that micro banking image significantly influences customer satisfaction. The path coefficient value of micro banking image against customer loyalty is 0.257 with $\mathrm{T}$ value of 2.412 and $\mathrm{P}$ value $=0.0160$. This shows that the $\mathrm{t}$ count value of path coefficient of micro banking image variable against customer loyalty is within H0's area of rejection, which means that micro banking image significantly influences customer loyalty. The path coefficient value of customer satisfaction against customer loyalty is 0.263 with $\mathrm{T}$ value of 2.299 and $\mathrm{P}$ value $=0.0210$. This shows that the $\mathrm{t}$ count value of path coefficient of customer satisfaction variable against customer loyalty is within H0's area of rejection, which means that customer satisfaction significantly influences customer loyalty. The path coefficient value of customer relationship against micro banking image is 0.308 with $\mathrm{T}$ value of 2.766 and $\mathrm{P}$ value $=0.006$. This means that the $\mathrm{t}$ count value of path coefficient of customer relationship variable against micro banking image is within H0's area of rejection, which means that customer relationship significantly influences micro banking image. The path coefficient value of customer relationship against customer satisfaction is 0.289 with $\mathrm{T}$ value of 2.299 and $\mathrm{P}$ value $=0.021$. This means that the $t$ count value of path coefficient of customer relationship variable against customer satisfaction is within H0's area of rejection, which means that customer relationship significantly influences customer satisfaction. The path coefficient value of customer relationship against customer loyalty is 0.290 with $\mathrm{T}$ value of 2.625 and $\mathrm{P}$ value $=0.009$. This means that the $t$ count value of path coefficient of customer relationship variable against customer loyalty is within H0's area of rejection, which means that customer relationship significantly influences customer loyalty. The seventh and eighth hypotheses are on mediation. The results of analysis on mediation are given in Table 4. 
Table 4

The mediating effect of image, interaction quality, service quality and consumer satisfaction

\begin{tabular}{|c|c|c|c|c|c|}
\hline Independent Variable & Mediation Variable & Dependent Variable & $\mathrm{t}$ count & P Value & Result \\
\hline Micro banking image & Consumer satisfaction & Consumer loyalty & 1.507 & 0.1316 & Not Support \\
\hline Customer relationship & Consumer satisfaction & Consumer loyalty & 1.426 & 0.1536 & Not Support \\
\hline
\end{tabular}

Based on Table 4, we may examine that the t count value of mediation test result between micro banking image-customer satisfaction- customer loyalty is 1.507 with $\mathrm{P}$ value $=0.1316$. This means that customer satisfaction is not mediated between micro banking image and customer loyalty. Similarly, the result of mediation test between customer relationship-customer satisfaction-customer loyalty is 1.426 with $\mathrm{P}$ value $=0.1536$. This means that customer satisfaction is not mediated between customer relationship and customer loyalty. Based on the seventh and eighth tests with Sobel test, we may conclude that customer satisfaction does not mediate the relationship of micro banking image and customer loyalty. Similarly with subsequent test result, we may conclude that customer satisfaction does not mediate customer relationship and customer loyalty. The result of mediation test using Sobel $t$ Test shows that the data obtained does not support the seventh and eighth hypotheses.

\subsection{Discussion}

The results of path analysis on the data show that company image positively influences customer satisfaction. This means that efforts made by micro banking company to improve its image with location, merchandise, customer service, price, advertising, and personal selling indicators are able to make customers satisfied in establishing business transactional relationship with micro banking company. This image improvement may be made by choosing strategic office location, micro credit product, better customer service, competitive interest rate, advertisement and establishing good relationship through salesperson in micro credit market. That the influence of micro banking company image exists shows that the results of this research support previous researches conducted by Bolton and Drew (1991), (Chang \& Fong, 2010; Lai et al., 2009; Wallin Andreassen \& Lindestad, 1998). The results of path analysis on the data show that company image positively influences customer loyalty. This means that efforts made by micro banking company to improve its image are able to make customers more loyal to micro banking company. That the influence of micro banking company image on loyalty exists shows that the results of this research support previous researches conducted by (Giovanis et al., 2014; Hart \& Rosenberger III, 2004; Kandampully \& Suhartanto, 2000). Loyalty is also influenced by customer satisfaction. This shows that the more satisfied a customer with micro banking service, the more loyal he/she is to the company by making word of mouth communication, repeated purchase and performing identification before purchase.

The results of this research support previous researches conducted by Yang and Peterson (2004), El-Adly and Eid (2016) and Han and Hyun (2018). According to the results of subsequent test, we may examine that customer relationship influences company image, customer satisfaction and customer loyalty. This means that better relationship with customers will improve company image, customer satisfaction and customer loyalty. The research results of customer relationship variable are consistent with the researchers conducted by Nyadzayo and Khajehzadeh (2016), Zhang et al. (2016), (Hassan et al., 2015). Micro banking companies can improve customer satisfaction by improving the image of micro banking by improving indicators of location, merchandise, customer service, price, advertising, and personal selling. The relationship with consumers also needs to be improved by paying attention to increasing competence, communication, conflict handling, trust, and relationship quality. Improvements to consumer satisfaction will increase and consumer loyalty. This research has limitations related to customer loyalty. This is because consumers tend to have more than one bank account in both micro and general banking. Subsequent research is expected to include general banking account ownership as a moderating variable.

\section{Conclusion}

According to the data analysis results, we may conclude that the influence of exogenous variable on endogenous variable in this research is significant. The most significant influence is that of customer relationship variable on micro banking company image, which is followed by the influence of customer relationship on customer loyalty. According to the text results of goodness of fit index, we may examine that the established models are strong ones, since all assumptions in the SEM AMOS software are fulfilled. However, the placement of customer satisfaction as mediation variable is weak, thus the customer satisfaction variable cannot become a mediation variable between company image and customer relationship.

\section{References}

Al-Alak, B. A. (2014). Impact of marketing activities on relationship quality in the Malaysian banking sector. Journal of Retailing and Consumer Services, 21(3), 347-356.

Albaity, M., \& Melhem, S. B. (2017). Novelty seeking, image, and loyalty-The mediating role of satisfaction and moderating role of length of stay: International tourists' perspective. Tourism management perspectives, 23, 30-37.

Anderson, R. E., \& Srinivasan, S. S. (2003). E-satisfaction and e-loyalty: A contingency framework. Psychology \& Marketing, 20(2), 123-138. 
Anonim. (2016). Statistik Lembaga Keuangan Mikro Indonesia. Retrieved 9 Juli, 2018, from https:/www.ojk.go.id/id/kanal/iknb/data-dan-statistik/statistik-lkm/

Anonim. (2018). Optimalisasi Lembaga Keuangan Dalam Pembiayaan Usaha Mikro, Kecil, dan Menengah (UMKM). Retrieved 9 Juli, 2018, from http://www.fiskal.kemenkeu.go.id

Assael, H. (1984). Consumer behavior and marketing action: Kent Pub. Co.

Bloemer, J., \& De Ruyter, K. (1998). On the relationship between store image, store satisfaction and store loyalty. European Journal of Marketing, 32(5/6), 499-513.

Bolton, R. N. (2016). Service Excellence: Creating Customer Experiences that Build Relationships: Business Expert Press.

Bolton, R. N., \& Drew, J. H. (1991). A multistage model of customers' assessments of service quality and value. Journal of consumer research, 17(4), 375-384.

Brunner, T. A., Stöcklin, M., \& Opwis, K. (2008). Satisfaction, image and loyalty: new versus experienced customers. European journal of marketing, 42(9/10), 1095-1105.

Castaldo, S., Grosso, M., Mallarini, E., \& Rindone, M. (2016). The missing path to gain customers loyalty in pharmacy retail: The role of the store in developing satisfaction and trust. Research in Social and Administrative Pharmacy, 12(5), 699712.

Chang, N.-J., \& Fong, C.-M. (2010). Green product quality, green corporate image, green customer satisfaction, and green customer loyalty. African Journal of Business Management, 4(13), 2836-2844.

Chen, C.-F., \& Chen, F.-S. (2010). Experience quality, perceived value, satisfaction and behavioral intentions for heritage tourists. Tourism management, 31(1), 29-35.

Chen, S.-C. (2012). The customer satisfaction-loyalty relation in an interactive e-service setting: The mediators. Journal of Retailing and Consumer Services, 19(2), 202-210.

Cronin Jr, J. J., Brady, M. K., \& Hult, G. T. M. (2000). Assessing the effects of quality, value, and customer satisfaction on consumer behavioral intentions in service environments. Journal of Retailing, 76(2), 193-218.

Cronin Jr, J. J., \& Taylor, S. A. (1992). Measuring service quality: a reexamination and extension. The journal of marketing, 55-68.

Dewani, P. P., Sinha, P. K., \& Mathur, S. (2016). Role of gratitude and obligation in long term customer relationships. Journal of Retailing and Consumer Services, 31, 143-156.

Dimitriades, Z. S. (2006). Customer satisfaction, loyalty and commitment in service organizations: Some evidence from Greece. Management Research News, 29(12), 782-800.

Doyle, P., \& Fenwick, I. (1974). How store image affects shopping habits in grocery chains. Journal of Retailing, 50(4), 3952.

El-Adly, M. I., \& Eid, R. (2016). An empirical study of the relationship between shopping environment, customer perceived value, satisfaction, and loyalty in the UAE malls context. Journal of Retailing and Consumer Services, 31, $217-227$.

Ferdinand, A. (2002). Structural equation modeling dalam penelitian manajemen. Semarang: Badan Penerbit Universitas Diponegoro.

Fornell, C. (1992). A national customer satisfaction barometer: The Swedish experience. The journal of marketing, 6-21.

Ghozali, I. (2006). Aplikasi analisis multivariate dengan program SPSS: Badan Penerbit Universitas Diponegoro.

Giovanis, A. N., Zondiros, D., \& Tomaras, P. (2014). The antecedents of customer loyalty for broadband services: The role of service quality, emotional satisfaction and corporate image. Procedia-Social and Behavioral Sciences, 148, $236-244$.

Griffin, J. (1995). Customer loyalty: How to get it, how to keep it. San Francisco: Jossey-Bass Press.

Grönroos, C. (2007). Service management and marketing: customer management in service competition: John Wiley \& Sons.

Han, H., \& Hyun, S. S. (2018). Role of motivations for luxury cruise traveling, satisfaction, and involvement in building traveler loyalty. International Journal of Hospitality Management, 70, 75-84.

Hart, A. E., \& Rosenberger III, P. J. (2004). The effect of corporate image in the formation of customer loyalty: An Australian replication. Australasian Marketing Journal (AMJ), 12(3), 88-96.

Hassan, R. S., Nawaz, A., Lashari, M. N., \& Zafar, F. (2015). Effect of customer relationship management on customer satisfaction. Procedia economics and finance, 23, 563-567.

Hennig-Thurau, T., \& Klee, A. (1997). The impact of customer satisfaction and relationship quality on customer retention: A critical reassessment and model development. Psychology \& Marketing, 14(8), 737-764.

Hyun, S. S., \& Perdue, R. R. (2017). Understanding the dimensions of customer relationships in the hotel and restaurant industries. International Journal of Hospitality Management, 64, 73-84.

Kandampully, J., \& Suhartanto, D. (2000). Customer loyalty in the hotel industry: the role of customer satisfaction and image. International journal of contemporary hospitality management, 12(6), 346-351.

Keaveney, S. M., \& Hunt, K. A. (1992). Conceptualization and operationalization of retail store image: A case of rival middlelevel theories. Journal of the Academy of Marketing Science, 20(2), 165-175.

Keller, K. L. (1993). Conceptualizing, measuring, and managing customer-based brand equity. The Journal of Marketing, 122.

Kotler, P., \& Amstrong, G. (2004). Prinsip-prinsip Marketing. Edisi Ketujuh, Penerbit Salemba Empat, Jakarta.

Lahap, J., Ramli, N. S., Said, N. M., Radzi, S. M., \& Zain, R. A. (2016). A Study of Brand Image towards Customer's Satisfaction in the Malaysian Hotel Industry. Procedia-Social and Behavioral Sciences, 224, 149-157.

Lai, F., Griffin, M., \& Babin, B. J. (2009). How quality, value, image, and satisfaction create loyalty at a Chinese telecom. Journal of business research, 62(10), 980-986. 
LeBlanc, G., \& Nguyen, N. (1996). An examination of the factors that signal hotel image to travellers. Journal of vacation Marketing, 3(1), 32-42.

Lee, J.-S., Hsu, L.-T., Han, H., \& Kim, Y. (2010). Understanding how consumers view green hotels: how a hotel's green image can influence behavioural intentions. Journal of sustainable tourism, 18(7), 901-914.

Lee, J., Lee, J., \& Feick, L. (2001). The impact of switching costs on the customer satisfaction-loyalty link: mobile phone service in France. Journal of services marketing, 15(1), 35-48.

Liang, L. J., Choi, H. C., \& Joppe, M. (2018). Exploring the relationship between satisfaction, trust and switching intention, repurchase intention in the context of Airbnb. International Journal of Hospitality Management, 69, 41-48.

Martineau, P. (1958). The personality of the retail store.

Mithas, S., Krishnan, M. S., \& Fornell, C. (2005). Why do customer relationship management applications affect customer satisfaction? Journal of Marketing, 69(4), 201-209.

Mowen, J. C., \& Minor, M. (2002). Perilaku konsumen. Jakarta: Erlangga, 90.

Nakhleh, H. M. (2012). The relationship between customer relationship marketing tactics, relationship quality and customer's loyalty in mobile communication industry. Academic Research International, 3(2), 538.

Ndubisi, N. O. (2004). Knowledge management: a case of 'search and replace marketing' or an emerging field of management. Asian Academy of Management Journal, 9(1), 29-52.

Ngobo, P.-V., \& Jean, S. (2012). Does store image influence demand for organic store brands? Journal of Retailing and Consumer Services, 19(6), 621-628.

Nyadzayo, M. W., \& Khajehzadeh, S. (2016). The antecedents of customer loyalty: A moderated mediation model of customer relationship management quality and brand image. Journal of Retailing and Consumer Services, 30, $262-270$.

Olavarría-Jaraba, A., Cambra-Fierro, J. J., Centeno, E., \& Vázquez-Carrasco, R. (2018). Relationship quality as an antecedent of customer relationship proneness: A cross-cultural study between Spain and Mexico. Journal of Retailing and Consumer Services, 42, 78-87.

Oliver, R. L. (1997). Satisfaction: A Behavioral Perspective on the Consumer. New YorN: McGraw-Hill, 40, 69-71.

Ostrowski, P. L., O'Brien, T. V., \& Gordon, G. L. (1993). Service quality and customer loyalty in the commercial airline industry. Journal of travel research, 32(2), 16-24.

Padmavathy, C., Balaji, M., \& Sivakumar, V. (2012). Measuring effectiveness of customer relationship management in Indian retail banks. International Journal of Bank Marketing, 30(4), 246-266.

Pearson, S. (1996). Building Brands Directly: Creating Business Value from Customer Relationship. McMillan Business, 116 , 20.

Pizam, A., Neumann, Y., \& Reichel, A. (1978). Dimentions of tourist satisfaction with a destination area. Annals of tourism Research, 5(3), 314-322.

Ratanavaraha, V., Jomnonkwao, S., Khampirat, B., Watthanaklang, D., \& Iamtrakul, P. (2016). The complex relationship between school policy, service quality, satisfaction, and loyalty for educational tour bus services: A multilevel modeling approach. Transport Policy, 45, 116-126.

Ravald, A., \& Grönroos, C. (1996). The value concept and relationship marketing. European journal of marketing, 30(2), 1930.

Rein, I., Kotler, P., \& Haider, D. (1993). Marketing Places: Attracting Investment, Industry, and Tourism to Cities, States, and Nations.

Rust, R. T., Lemon, K. N., \& Zeithaml, V. A. (2004). Return on marketing: Using customer equity to focus marketing strategy. Journal of Marketing, 68(1), 109-127.

Tjiptono, F. (2004). Manajemen jasa: Yogyakarta: Andi.

Truong, T.-H., \& Foster, D. (2006). Using HOLSAT to evaluate tourist satisfaction at destinations: The case of Australian holidaymakers in Vietnam. Tourism management, 27(5), 842-855.

Wallin Andreassen, T., \& Lindestad, B. (1998). Customer loyalty and complex services: The impact of corporate image on quality, customer satisfaction and loyalty for customers with varying degrees of service expertise. International Journal of service Industry management, 9(1), 7-23.

Wang, F., \& Head, M. (2005). Consumer relationship marketing on the Internet: An overview and clarification of concepts. Marketing, 1,1 .

Woodside, A. G., Frey, L. L., \& Daly, R. T. (1989). Linking sort/ice anlity, customer satisfaction, and behavioral intention. Journal of health care marketing, 9(4), 5-17.

Yang, Z., \& Peterson, R. T. (2004). Customer perceived value, satisfaction, and loyalty: The role of switching costs. Psychology \& Marketing, 21(10), 799-822.

Zhang, R., Li, G., Wang, Z., \& Wang, H. (2016). Relationship value based on customer equity influences on online groupbuying customer loyalty. Journal of Business Research, 69(9), 3820-3826. 
(C) 2020 by the authors; licensee Growing Science, Canada. This is an open access article distributed under the terms and conditions of the Creative Commons Attribution (CC-BY) license (http://creativecommons.org/licenses/by/4.0/). 